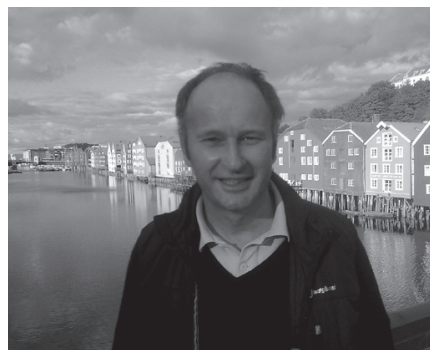

\title{
In Memorial: Phil Scott 1953-2011
}

It was with shock and deep sadness we received the message that Phil Scott died on July $15^{\text {th }}$, suddenly and unexpectedly.

Phil Scott was Professor of Science Education at Centre for Studies in Science and Mathematics Education (CSSME) at the University of Leeds, UK. Since 2008 he also held an adjunct professorship at the Department of Physics, Norwegian University of Science and Technology. He was one of Europe's most distinguished science educators, and has had a profound impact on science education research in the Nordic countries. Phil's insights, enthusiasm and intense passion for good science teaching have been a great inspiration to so many of us in our research and teacher training.

Phil had a long experience as a science and physics teacher. After having finished undergraduate studies and teacher training in 1975, he served as a teacher for 13 years, the later years also as Head of the school's Physics Department. During this period he got involved with science education research through the Children's Learning in Science (CLIS) project, directed by Professor Rosalind Driver at the University of Leeds. The project and the group's further work led to very influential insights for science education, in terms of theoretical perspectives on learning in science as well as an empirical basis for how we can understand students' conceptions of science and the nature of scientific knowledge. Some publications Phil contributed to at an early stage in his academic career are still being referred to in science education research internationally.

Phil did a Masters' degree in science education and was in 1988 appointed as a Lecturer at School of Education at the University of Leeds. He completed his PhD in 1997, with a thesis on how Lev S. Vygotsky's theories can be used to understand pedagogical interactions that support students' learning in science. Language and communication in science teaching with basis in Vygotsky's theories remained a focal point of his research, and he developed it further and published extensively. In particular, the book Meaning Making in Secondary Science Classrooms (2003) he co-authored with Eduardo Mortimer has been influential worldwide. (Eduardo is currently about to publish their second book, which the world of science education is looking forward to.) In 2004, Phil was appointed Professor of Science Education at the School of Education, University of Leeds, where he also has been the Director of Centre for Studies in Science and Mathematics Education since 2008.

This centre has had a major significance for building up science education research not only in UK but also in the Nordic countries. CSSME has had close links to researchers of science education in our countries. In the case of Norway this is partly due to the fact that our first professor of science education, Professor Svein Sjøberg at the University of Oslo, began his way into the research field by doing a Master's degree (1975) in science education in Rosalind Driver's research group at Leeds. In all the years that have followed, the contact has been maintained and developed by Svein but also by new generations of science educators. Many of us have been in Leeds for shorter or longer stays, often as a stepping stone for our own research in science education. The vibrant research community at CSSME is a vital source for insights and inspiration, and we are always warmly welcomed there. 
Phil Scott has been such an important part of this experience for all of us, as a teacher, mentor and colleague. He was an exceptionally warm and enthusiastic person; he supported newcomers in the field and celebrated our success. Phil often made me feel I were the most brilliant and talented person on earth. I always knew it was not true, but his energetic support nevertheless helped me realising my potential - and a bit more. Many people who were his colleagues and students have benefited from Phil's support and supervision in similar ways.

In later years Phil often visited the Nordic countries. It seemed he enjoyed coming up north, and he was a very popular speaker at conferences and courses. Just before the summer, only two months before he passed away, Phil contributed as a keynote speaker at The Visions Conference at the University of Oslo, celebrating its 200 years anniversary this year. He also held keynotes at the Swedish symposium in Kristiansstad, November 2010, and at the Nordic symposium NFSUN in Reykjavik in 2008. At our Nordic-Baltic course The Role of Theory in Science Education in Gothenburg, 2008, Phil contributed with engaging lectures and valuable group supervision for $\mathrm{PhD}$ students and colleagues from all Nordic and Baltic countries. In Denmark, he mediated the collaboration between CSSME and Centre for Science Education at Aarhus University, and in Finland he worked as a trainer at the Graduate School for Mathematics and Science Education in Helsinki. Phil has supervised several Nordic PhD students, and he worked with us in establishing the Nordic research network NorSEd, which in 2010 received financial support for three years from NordForsk.

In Trondheim, I had the great privilege of working closely with him in building up PhD courses in science education at The Norwegian University of Science and Technology. The courses were run in 2008 and 2010, the last time with participants from all Nordic countries with support from NorSEd. The seminars were such great events! Phil was amazing with students. In very neat ways he managed to go into depth in highly academic matters and still demonstrate how it makes sense from the perspective of the classroom. Phil always reminded us that our research needs to have a message to tell the science teacher. And somehow Sunderland Football Club also managed to creep into most of his lectures.

Phil was exceptionally talented in engaging an audience. This does not mean it came by itself. He worked extremely hard; he utilised every minute in hotel rooms and airports so even the smallest performance was very well prepared. He enjoyed the positive feedback in a charming - almost childlike - way, but was very quick to share the credits: "Well done, us!" Phil usually said and winked to me after another successful course event. He was a magnificent colleague and mentor and such a good friend.

It is hard for us all to understand that Phil will no more be with us. However, his work and good spirit will remain with us, and we share so many fine memories. The memorial page on Facebook, entitled In memory of Professor Phil Scott, where people post pictures, thoughts and memories, provides a beautiful representation of an amazing person that meant so much to so many people. (The page can be viewed by everyone without registering into Facebook.)

We are grateful that Phil Scott was one of us. Our warm thoughts go to Phil's colleagues in Leeds and to his wife, his two daughters and his much loved grandson baby Thomas in a very difficult time.

We all miss you, Phil.

Berit Bungum, The Norwegian University of Science and Technology 